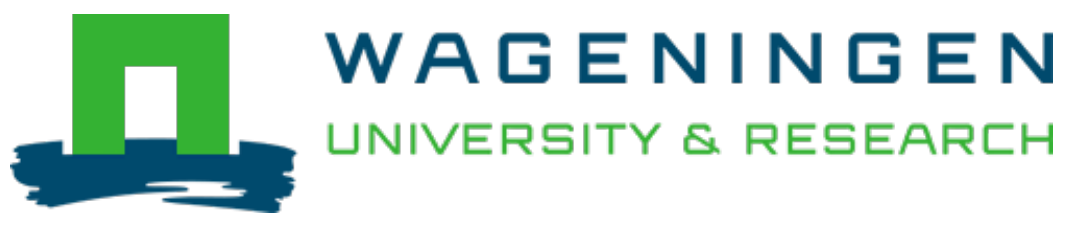

\title{
Microbial changes during the production of Sufu - a Chinese fermented soybean food
}

\author{
Food Control \\ Han, B.; Cao, C.F.; Rombouts, F.M.; Nout, M.J.R. \\ https://doi.org/10.1016/S0956-7135(03)00066-5
}

This publication is made publicly available in the institutional repository of Wageningen University and Research, under the terms of article $25 \mathrm{fa}$ of the Dutch Copyright Act, also known as the Amendment Taverne. This has been done with explicit consent by the author.

Article 25 fa states that the author of a short scientific work funded either wholly or partially by Dutch public funds is entitled to make that work publicly available for no consideration following a reasonable period of time after the work was first published, provided that clear reference is made to the source of the first publication of the work.

This publication is distributed under The Association of Universities in the Netherlands (VSNU) 'Article $25 \mathrm{fa}$ implementation' project. In this project research outputs of researchers employed by Dutch Universities that comply with the legal requirements of Article $25 \mathrm{fa}$ of the Dutch Copyright Act are distributed online and free of cost or other barriers in institutional repositories. Research outputs are distributed six months after their first online publication in the original published version and with proper attribution to the source of the original publication.

You are permitted to download and use the publication for personal purposes. All rights remain with the author(s) and / or copyright owner(s) of this work. Any use of the publication or parts of it other than authorised under article $25 \mathrm{fa}$ of the Dutch Copyright act is prohibited. Wageningen University \& Research and the author(s) of this publication shall not be held responsible or liable for any damages resulting from your (re)use of this publication.

For questions regarding the public availability of this publication please contact openscience.library@wur.nl 


\title{
Microbial changes during the production of Sufu-a Chinese fermented soybean food
}

\author{
Bei-Zhong Han ${ }^{\text {a,b }}$, Cui-Feng Cao ${ }^{\text {a }}$, Frans M. Rombouts ${ }^{\mathrm{b}}$, M.J. Robert Nout ${ }^{\mathrm{b}, *}$ \\ ${ }^{\text {a }}$ College of Food Science and Nutritional Engineering, China Agricultural University, Beijing 100083, China \\ ${ }^{\mathrm{b}}$ Laboratory of Food Microbiology, Department of Agrotechnology \& Food Sciences, Wageningen University, P.O. Box 8129, \\ 6700 EV Wageningen, The Netherlands
}

Received 13 January 2003; received in revised form 21 March 2003; accepted 31 March 2003

\begin{abstract}
Sufu is a Chinese soybean cheese obtained by solid-state fungal fermentation of tofu followed by ripening in dressing mixture. The aim of this study was to quantify microflora changes during the sufu process, which is carried out under non-sterile conditions. From tofu to pehtze (tofu overgrown with fungus) stages, total counts of mesophilic aerobic bacteria (TMAB), bacterial endospores (spores), Bacillus cereus, lactic acid bacteria (LAB), Enterobacteriaceae and fungi increased. All of them decreased after the salting of pehtze. TMAB and spores in sufu with $8 \%$ and $11 \%$ salt content decreased to around $10^{6}$ cfu/g during the ripening. B. cereus remained at around $10^{3} \mathrm{cfu} / \mathrm{g}$. LAB in sufu with $8 \%$ and $11 \%$ salt content decreased gradually to $<10^{2} \mathrm{cfu} / \mathrm{g}$, but increased to $10^{9} \mathrm{cfu} /$ $\mathrm{g}$ in sufu with $5 \%$ salt. Enterobacteriaceae and fungi decreased to non-detectable level after 20 and 30 days of maturation.

(c) 2003 Elsevier Ltd. All rights reserved.
\end{abstract}

Keywords: Tofu; Sufu; Microflora; Fermented soybean; Lactic acid bacteria

\section{Introduction}

Sufu, Fu-ru written in hieroglyphics, is a fermented soybean food that originated in China. It is a soft creamy cheese-type product made from cubes of soybean curd (tofu) by the action of a mould (Steinkraus, 1996; Su, 1986). For many centuries, this fermented product with its characteristic flavour has been widely consumed by Chinese people as an appetiser.

Different types of sufu are produced by various local processors in China (Wang \& Du, 1998), with mouldfermented sufu being the most popular type of product (Han, Rombouts, \& Nout, 2001b). Four steps are normally involved in making this type of sufu: (1) Preparing tofu (soybean curd), (2) Preparing pehtze (pizi) by fungal solid-state fermentation of tofu using e.g. Actinomucor elegans, (3) salting of pehtze, and (4) ripening in

\footnotetext{
${ }^{*}$ Corresponding author. Address: Laboratory of Food Microbiology, Department of Agrotechnology \& Food Sciences, Wageningen University, P.O. Box 8129, 6700 EV Wageningen, The Netherlands. Tel.: +31-317-482834; fax: +31-317-484978.

E-mail address: rob.nout@wur.nl (M.J.R. Nout).
}

dressing mixture (Wang \& Hesseltine, 1970). The composition of the dressing mixture will determine the type of sufu (red or white) that is obtained.

The sufu process and variations in recipes and compositions were described by Han et al. (2001b) and Su (1986). The pure culture starters mainly consist of moulds-Mucoraceae (Actinomucor, Mucor and Rhizopus) or bacteria-Micrococcus and Bacillus spp. Although a pure culture is used in the pehtze fermentation, the process of sufu manufacture itself is carried out under non-sterile conditions, and by consequence other functional microbes may be involved in sufu production, while unwanted microbial contamination will occur as well as was shown in commercial samples (Han, Beumer, Rombouts, \& Nout, 2001a).

As in some other fermented foods, such as cheese (Messens, Dewettinck, \& Huyghebaert, 1999) and miso (Chiou, Ferng, \& Beuchat, 1999), salt plays a very important role in sufu. It imparts a salty taste to the products, and it also serves to control the microbial growth and the enzyme activity.

Although most sufu contains considerable levels of the antimicrobial $\mathrm{NaCl}(6-15 \% \mathrm{w} / \mathrm{w})$ and ethanol $(0-7 \%$ $\mathrm{v} / \mathrm{v})($ Han et al., 2001a) that could prevent the survival 
or growth of contaminating microbes, it may be expected that some endospore-forming bacteria such as Bacillus spp. could grow since these vary greatly in their salt tolerance (Brewer, 2000). The fact that several bacteria have a remarkable ability to survive different environmental stress conditions makes it very difficult for the food industry to exclude them from their products (Andersson, Rönner, \& Granum, 1995). The role of such microbes other than starters during sufu production is still unknown.

Tofu is an essential raw material for sufu production. The microbiological quality of tofu was studied by Tuitemwong and Fung (1991), and high levels of bacteria were observed. Foodborne pathogenic bacteria, such as Enterobacteriaceae, B. cereus and Staphylococcus aureus were also found in commercial tofu (Ashraf, White, \& Klubek, 1999; Rehberger, Wilson, \& Glatz, 1984; Van Kooij \& De Boer, 1985). Earlier investigations of commercial sufu revealed the presence of high levels of bacteria (especially bacterial endospores) and considerable levels of foodborne pathogenic bacteria such as B. cereus (Han et al., 2001a; Pao, 1994; Shi \& Fung, 2000). But so far, much less information is available about the microflora changes taking place during the production of red and white sufu.

The sufu manufacturing industry has an interest in reducing salt levels in the product for several reasons, mainly to reduce the ripening period. Since it may be expected that lower salt contents will be detrimental to microbiological stability, the effects of salt on the microflora are presented here.

\section{Materials and methods}

\subsection{Microorganism}

A. elegans (Academia Sinica AS 3.227) is commonly used as a starter in commercial sufu production in China. A pure culture inoculum of A. elegans AS 3.227 was prepared, starting from agar slant culture, by liquid substrate culture in Roux bottles as is practised in Chinese sufu factories. The medium consisted of soy whey (byproduct from tofu manufacture) to which maltose $(2-3 \% \mathrm{w} / \mathrm{v})$ and neutral peptone $(1.5-2.0 \% \mathrm{w} / \mathrm{v})$ were added prior to sterilisation by autoclaving $\left(115^{\circ} \mathrm{C}\right.$, $15 \mathrm{~min}$ ). After static incubation at $28{ }^{\circ} \mathrm{C}$ for $72 \mathrm{~h}$, medium and biomass were harvested and homogenised by a colloid mill to obtain an inoculum suspension containing $\sim 10^{5} \mathrm{CFU} / \mathrm{ml}$.

\subsection{Sufu preparation}

The tofu used as raw material for sufu was provided by Beijing WangZhiHe sufu manufacturer, and was cut into pieces $(3.2 \times 3.2 \times 1.6 \mathrm{~cm})$. The pieces were inocu- lated with $A$. elegans by spraying inoculum suspension onto the surface of tofu pieces with manually operated sprayers, comparable to those used for spraying plants. The inoculated pieces were placed evenly spaced, in plastic trays. The loaded trays were piled up in an incubation room with controlled temperature (around 25 ${ }^{\circ} \mathrm{C}$ ), relative humidity (around 90\%) and air circulation to ensure adequate aeration. Relative humidity was measured by a hygrometer and controlled by spraying water manually. Fresh pehtze, i.e. tofu overgrown with A. elegans mycelium, was obtained after incubation for $48 \mathrm{~h}$.

The 1250 pieces (about $21 \mathrm{~kg}$ ) of pehtze were transferred into a container (capacity $20 \mathrm{l}$ ) and $3.5 \mathrm{~kg}$ purified sea-salt was spread between layers of pehtze as they piled up in the container. During a period of 5 days, the pehtze absorbed the salt until the salt content of pehtze reached about $14 \%(\mathrm{w} / \mathrm{w})$ of wet weight.

For the ripening of sufu, 12 pieces of salted pehtze (about $210 \mathrm{~g}$ fresh weight) were placed in individual wide-mouthed glass bottles with a capacity of $340 \mathrm{ml}$, after which dressing mixture (about $140 \mathrm{ml}$ ) was added to the pehtze. In order to reach the required final salt level, less salted pehtze was placed in the bottle to obtain sufu with $5 \%(\mathrm{w} / \mathrm{w})$ salt content, and salt was added to some dressing mixtures to obtain sufu with $11 \%$ and $14 \%(\mathrm{w} / \mathrm{w})$ salt content. For red sufu, the dressing mixture consisted of angkak or kojic red rice $(2 \%)$ (Han et al., 2001b), alcoholic beverage (rice wine) (Nout \& Aidoo, 2002) to a final alcohol content of $5 \%(\mathrm{v} / \mathrm{v})$, sugar $(10 \%)$, Chiang (wheat-based miso) (3\%) (CampbellPlatt, 1987), and spices. For white sufu, the dressing mixture only consisted of alcoholic beverage (final alcohol content $5 \%$ ). The filled bottles were closed with plastic caps and then incubated at $25-28{ }^{\circ} \mathrm{C}$ for 80 days.

The whole procedure of sufu preparation was carried out under factory conditions in a factory.

\subsection{Sampling for analysis}

Two bottles were drawn randomly from each batch on each sampling day during the ripening period. Sufu pieces of duplicate bottles were combined and homogenised aseptically using mortar and pestle prior to analysis in duplicate. A $5 \mathrm{~g}$ sample of sufu was homogenised with $45 \mathrm{ml}$ demineralised water. The $\mathrm{pH}$ was measured in this suspension using a digital $\mathrm{pH}$ meter.

Representative $20 \mathrm{~g}$ portions of homogenised sufu were aseptically weighed, mixed with $180 \mathrm{ml}$ peptone saline $(0.1 \%$ neutral peptone, $2.5 \% \mathrm{NaCl})$ (except for tofu and pehtze samples) with higher than physiological salt concentration to minimise osmotic shock (Han et al., 2001a). Subsequent decimal dilutions were prepared with the same diluent, and in all cases, duplicate counting plates were prepared of appropriate dilutions. 


\subsection{Microbiological analysis}

\subsubsection{Total count of mesophilic aerobic bacteria}

Total count of mesophilic aerobic bacteria (TMAB) was enumerated in pour-plates of Plate Count Agar (PCA, CM325, Oxoid, England) to which $25 \mathrm{~g} \mathrm{NaCl}$ was added per litre, after incubation at $30{ }^{\circ} \mathrm{C}$ for $2-3$ days.

\subsubsection{Bacterial endospores (spores)}

Samples were pasteurised $\left(80{ }^{\circ} \mathrm{C}, 10 \mathrm{~min}\right)$ and spores were enumerated in pour-plates of PCA to which $25 \mathrm{~g}$ $\mathrm{NaCl}$ was added per litre, after incubation at $30{ }^{\circ} \mathrm{C}$ for 2-3 days.

\subsubsection{Bacillus cereus}

Selective enumeration was carried out on spreadplates of Mannitol Egg Yolk Polymyxin (MYP) (Cereus selective agar, catalogue no. 1.05267, Merck, Germany) to which $25 \mathrm{~g} \mathrm{NaCl}$ was added per litre. The inoculated plates were incubated at $30^{\circ} \mathrm{C}$ for $24 \mathrm{~h}$ and examined for typical colonies. Presumptive colonies (pink colonies surrounded by a zone of precipitation) were counted. Carbohydrate metabolism by isolates of bacilli was determined using API $50 \mathrm{CH}$ strips and API $50 \mathrm{CHB}$ medium (bioMérieux, Lyon, France) according to the manufacturer's instructions. The resulting biochemical profiles were interpreted using APILAB software (Version 3.3.3, 1990, bioMérieux, Lyon, France).

\subsubsection{Lactic acid bacteria}

Lactic acid bacteria (LAB) were enumerated in pourplates of de Man, Rogosa and Sharpe medium (MRS, catalogue no. 1.10661, Merck, Germany) to which $12 \mathrm{~g}$ agar, $25 \mathrm{~g} \mathrm{NaCl}$ and $2 \mathrm{~g}$ natamycin ("Delvocid", DSM, Delft, The Netherlands) were added per litre, after incubation at $30^{\circ} \mathrm{C}$ for $3-4$ days. Initial confirmation was based on positive Gram stain, and negative catalase and oxidase tests. Carbohydrate metabolism of isolates of LAB was determined using API $50 \mathrm{CH}$ strips and API 50 CHL medium (bioMérieux, Lyon, France) according to the manufacturer's instructions. Tentative identification based on phenotypical properties was done with IBIS software (Intelligent Bacteria Identification System, the Netherlands) (Wijtzes, Bruggeman, Nout, \& Zwietering, 1997).

\subsubsection{Enterobacteriaceae}

Selective enumeration was carried out in pour-plates of Violet Red Bile Glucose agar (VRBG, CM485, Oxoid, England) with overlay to which $25 \mathrm{~g} \mathrm{NaCl}$ was added, after incubation at $30^{\circ} \mathrm{C}$ for $24-36 \mathrm{~h}$.

\subsubsection{Yeasts and moulds (fungi)}

Fungi were enumerated in pour-plates of standard and salt-enriched Oxytetracycline Glucose-Yeast Extract agar (OGYE, CM545, Oxoid, England) to which 0 and $25 \mathrm{~g} \mathrm{NaCl}$ was added per litre, respectively, after incubation at $30^{\circ} \mathrm{C}$ for 5 days.

\section{Results and discussion}

Fig. 1 presents the microflora of tofu, pehtze and salted pehtze stages, which are intermediate products of sufu making, prior to the ripening procedure. Initial counts of TMAB, spores and LAB were around $10^{4}$ $\mathrm{cfu} / \mathrm{g}$, and B. cereus and Enterobacteriaceae were not detectable in tofu. After solid-state fermentation of tofu, high levels $\left(10^{7}-10^{9} \mathrm{cfu} / \mathrm{g}\right)$ of microflora (except for B. cereus $10^{3} \mathrm{cfu} / \mathrm{g}$ ) were found in pehtze as expected. Considerable decline of LAB, Enterobacteriaceae and fungi took place after salting of pehtze. On the other hand, spores and B. cereus were less affected. This implies that the salting can be a very effective operation for inactivating contaminating microbes, such as LAB and Enterobacteriaceae during sufu production.

In Fig. 2, the pH changes are shown during the 80 days ripening period. The $\mathrm{pH}$ of sufu with $8 \%$ and $11 \%$

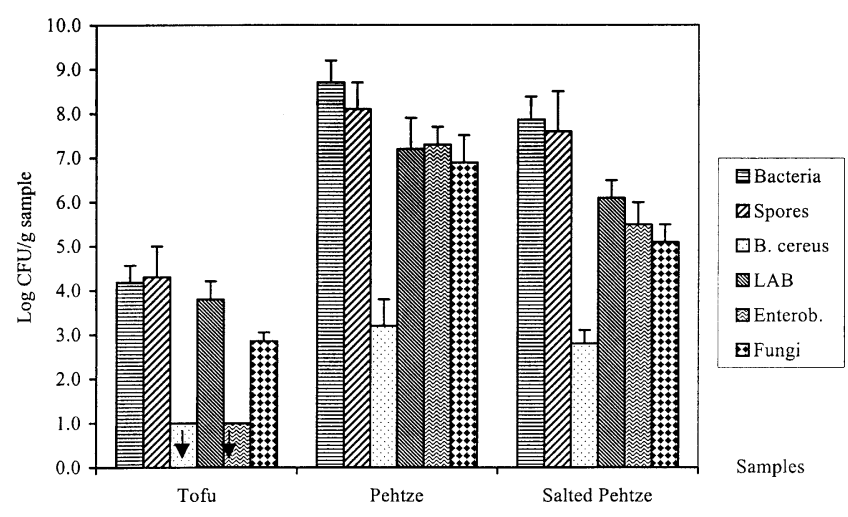

Fig. 1. Microflora of tofu, pehtze and salted pehtze. Spores: bacterial endospores; LAB: lactic acid bacteria; Enterob.: Enterobacteriaceae. Mean of duplicates; bars indicate range.

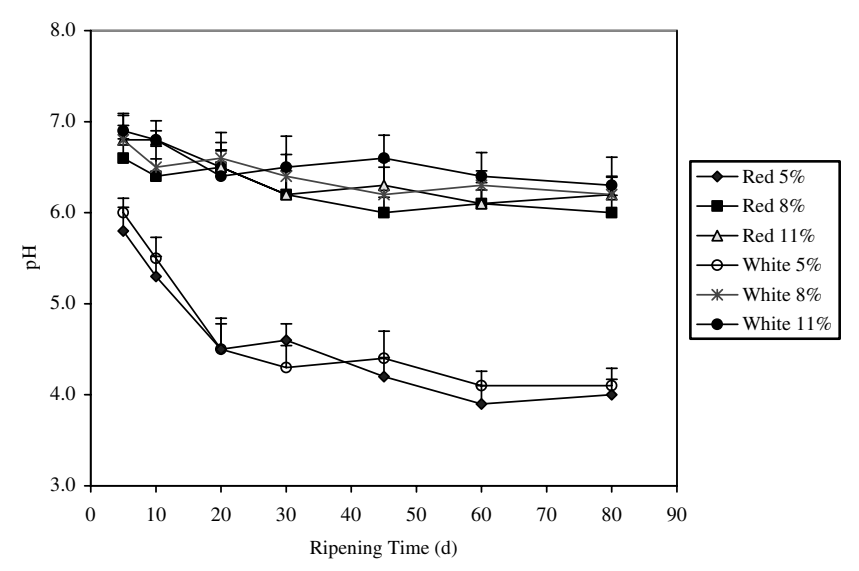

Fig. 2. $\mathrm{pH}$ changes during the ripening of sufu with different salt contents. Mean of duplicates; bars indicate range. 
salt content decreased slightly, and remained in the range of $6-7$. But the $\mathrm{pH}$ of sufu with $5 \%$ salt content decreased rapidly during the first 20 days, and then decreased slowly to around 4, indicating that this sufu was spoiled after 20 days as evidenced by low $\mathrm{pH}(<4.6)$ and off-flavour.

In Fig. 3, changes of TMAB during sufu ripening are shown. TMAB in sufu with $5 \%$ salt content increased over $10^{9} \mathrm{cfu} / \mathrm{g}$ after ripening 30 days, and then remained at this level. TMAB in sufu with higher salt contents decreased to around $10^{6} \mathrm{cfu} / \mathrm{g}$ and stabilised after ripening 30 days. The number of TMAB in sufu with $8 \%$ salt content was a little higher than that in sufu with $11 \%$ salt content. There was no apparent difference between red sufu and white sufu.

Changes in spore numbers during sufu ripening are presented in Fig. 4. Numbers of spores changed in a similar way as the TMAB in sufu of higher salt content. However, they remained at high levels of around $10^{7}$ $\mathrm{cfu} / \mathrm{g}$ in sufu with $5 \%$ salt content during the ripening. Whereas spores in low salt acidifying product apparently did not germinate, in neutral, high salt products the number of spores decreased, presumably because of germination, and the resulting vegetative cells subsequently died.

From Figs. 3 and 4, the similar levels of corresponding counts of TMAB and spores at $8 \%$ and $11 \%$ salt content in the early phase of ripening indicate that TMAB mainly represented spores. About $85 \%$ of isolates taken from TMAB counting plates were indeed Gram-positive, mostly rod-shaped bacteria. This was as expected, since the resistance of Gram-positive bacteria to ethanol and salt is relatively higher than that of Gram-negative bacteria (Seiler \& Russell, 1991). Over $90 \%$ of isolates taken from spore counting plates were Gram-, oxidase- and catalase-positive, and rod-shaped. Based on their carbohydrate assimilation patterns, the randomly picked isolates from spore counting plates were identified as $B$. subtilis.
The presumptive colony counts of $B$. cereus on MYP were in the range of approximately $10^{3} \mathrm{cfu} / \mathrm{g}$ during sufu ripening, indicating they could neither grow nor be inactivated, regardless of the salt content and type of sufu. When presumptive $B$. cereus isolates were checked by carbohydrate metabolism, 21 strains $(87.5 \%$ of total) were confirmed to be B. cereus, and three strains $(12.5 \%$ of total) were $B$. subtilis. The enterotoxins produced by $B$. cereus are responsible for emetic and/or diarrhoeal food poisoning (Granum, 1994). B. cereus is a potential hazard for consumers when its number exceeds $10^{5} \mathrm{cfu} / \mathrm{g}$ (Andersson et al., 1995). Whereas the present study shows significantly lower levels $\left(10^{3} \mathrm{cfu} / \mathrm{g}\right)$, occasionally commercial samples exceed $10^{5} \mathrm{cfu} / \mathrm{g}$ (Han et al., 2001a), which should be of concern to the sufu industry.

Although LAB are involved as functional microflora in many fermented foods we consider them as undesirable spoilage-causing bacteria in sufu. In red sufu with $8 \%$ and $11 \%$ salt content, LAB decreased gradually from $10^{5}-10^{6}$ to $<10 \mathrm{cfu} / \mathrm{g}$ (red sufu) and $<10^{2} \mathrm{cfu} / \mathrm{g}$ (white sufu) after 60 days of ripening (Fig. 5). This is in line with our earlier findings (Han et al., 2001a) that LAB were hardly found in commercial red and white sufu. On the other hand, high levels $\left(>10^{6} \mathrm{cfu} / \mathrm{g}\right)$ of LAB were found in some commercial white sufu without any detectable spoilage phenomena (Han et al., 2001a). This may have been caused by production methods that allowed for survival of LAB in these specific samples.

In sufu with $5 \%$ salt content, $\mathrm{LAB}$ were found to increase during the first 30 days of the ripening, and remained around $10^{9} \mathrm{cfu} / \mathrm{g}$ (Fig. 5), indicating that the combination of $5 \%$ salt and $5 \%$ alcohol was not adequate to inhibit the growth of $\mathrm{LAB}$ in sufu. Isolates of presumptive LAB on MRS were Gram-positive, oxidase and catalase negative, non-sporeforming rod-shaped bacteria. They could grow under both aerobic and anaerobic conditions, produced acid from ribose but no gas from glucose, and were initially classified as facultative heterofermentative lactobacilli (Wijtzes et al.,

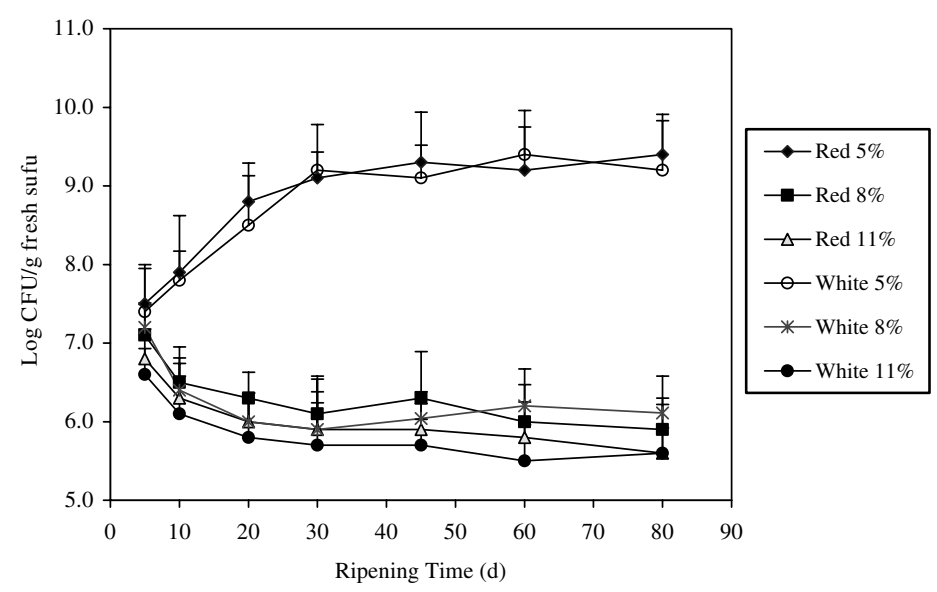

Fig. 3. Changes of TMAB during ripening of sufu with different salt contents. Mean of duplicates; bars indicate range. 


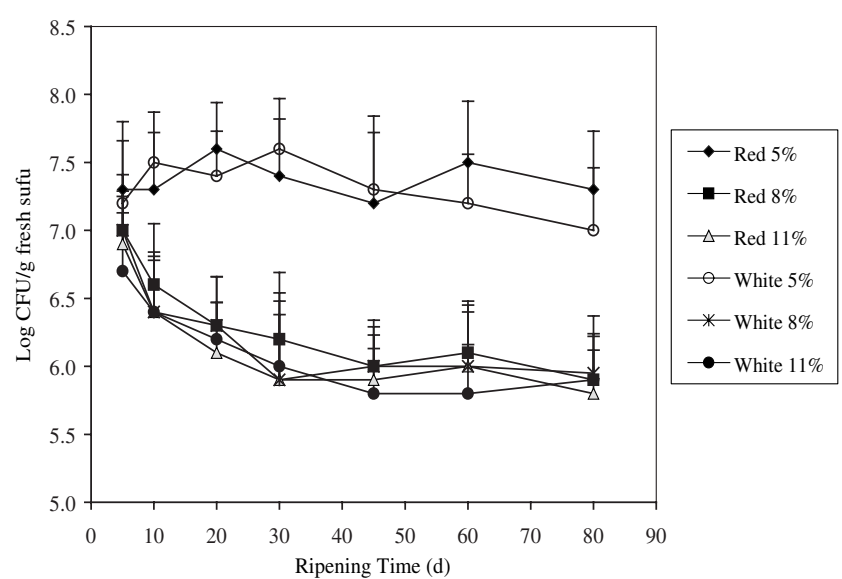

Fig. 4. Levels of bacterial endospores during ripening of sufu with different salt contents. Mean of duplicates; bars indicate range.

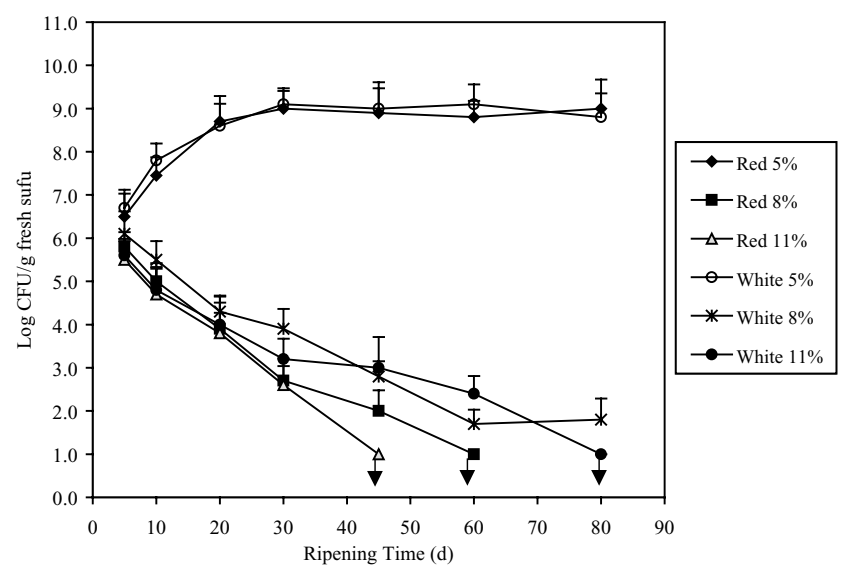

Fig. 5. Changes of LAB during ripening of sufu with different salt contents. Mean of duplicates; bars indicate range.

1997). Carbohydrate assimilation data indicated that these lactobacilli were most probably $L b$. curvatus.

From Figs. 3 and 5, the similar levels of corresponding TMAB and $\mathrm{LAB}$ counts found in sufu with $5 \%$ salt content, indicate that TMAB mainly represented lactobacilli including $L b$. curvatus, and that they contributed to the $\mathrm{pH}$ decrease and the spoilage of sufu with low salt content $(5 \%)$ during the ripening.

Most Enterobacteriaceae do not tolerate the combination of elevated levels of salt and alcohol. Whereas they were found at high levels $\left(>10^{7} \mathrm{cfu} / \mathrm{g}\right)$ in pehtze, they were inactivated steadily during the salting and ageing steps. The levels of Enterobacteriaceae are shown in Table 1. As was expected, no Enterobacteriaceae were detectable after 20 days in any of the samples (even sufu with $5 \%$ salt) using VRBG agar with or without $2.5 \%$ $\mathrm{NaCl}$, which corresponded to the earlier studies (Han et al., 2001a; Pao, 1994; Shi \& Fung, 2000). Coliforms were not found in the samples investigated by Pao (1994). Shi and Fung (2000) reported that the foodborne
Table 1

Changes of Enterobacteriaceae (log cfu/g fresh sufu) during ripening of sufu with different salt contents

\begin{tabular}{lllll}
\hline & $\begin{array}{l}\text { Ripening } \\
\text { time (days) }\end{array}$ & & \\
\cline { 2 - 5 } 5 & 5 & 10 & 20 & 30 \\
\hline Red $5 \%$ & $3.7-4.7^{\text {a }}$ & $1.7-2.9$ & $<1$ & $<1$ \\
Red $8 \%$ & $2.8-4.2$ & $1.5-1.9$ & $<1$ & $<1$ \\
Red $11 \%$ & $<1$ & $<1$ & $<1$ & $<1$ \\
White $5 \%$ & $4.0-5.0$ & $1.6-2.4$ & $<1$ & $<1$ \\
White $8 \%$ & $2.6-4.0$ & $<1$ & $<1$ & $<1$ \\
White $11 \%$ & $<1$ & $<1$ & $<1$ & $<1$ \\
\hline
\end{tabular}

${ }^{\mathrm{a}}$ Range of duplicate values.

pathogens Escherichia coli O157:H7, Salmonella typhimurium, and even $S$. aureus and Listeria monocytogenes were reduced to non-detectable levels after one month of ripening.

Although Enterobacteriaceae are unlikely to survive the final stages of the sufu process, their ability to grow and to possibly produce endotoxins during the early pehtze making stage might constitute a hazard. Consequently, toxicological studies would be helpful to assess the potential hazard posed by such toxins during sufu production.

Whereas the number of colony forming units of moulds does not correlate well with their biomass, they provide information about viability, Table 2 shows that fungi lost their viability $(<10 \mathrm{cfu} / \mathrm{g})$ in all samples after 30 days of ripening, as tested in OGYE agar with or without $2.5 \% \mathrm{NaCl}$. This result differs from the data of Pao (1994) who reported $10^{2}-10^{6} \mathrm{cfu} / \mathrm{g}$ of fungi in sufu. Shi and Fung (2000) mentioned that no moulds were detected in sufu samples after one, two and three months of ripening. Most likely the fungi, particularly the mould starters do not survive after the pehtze preparation, owing to the combination of salt and ethanol in the dressing mixtures applied for the maturation of sufu.

In conclusion, sufu containing $8 \%$ salt or more and $5 \%$ ethanol during the ripening stage is microbiologically stable and safe.

Table 2

Changes of fungi (log cfu/g fresh sufu) during ripening of sufu with different salt content

\begin{tabular}{llllll}
\hline \multicolumn{1}{c}{$\begin{array}{l}\text { Ripening } \\
\text { time } \\
\text { (days) }\end{array}$} & & & & \\
\cline { 2 - 6 } & 5 & 10 & 20 & 30 & 45 \\
\hline Red 5\% & $3.6-5.0^{\mathrm{a}}$ & $2.8-3.6$ & $1.8-2.4$ & $<1$ & $<1$ \\
Red $8 \%$ & $3.3-4.8$ & $2.1-2.9$ & $1.5-2.1$ & $<1$ & $<1$ \\
Red 11\% & $3.2-4.0$ & $2.4-3.2$ & $<1$ & $<1$ & $<1$ \\
White 5\% & $4.0-5.0$ & $3.0-3.8$ & $2.0-2.6$ & $<1$ & $<1$ \\
White $8 \%$ & $3.2-4.2$ & $1.6-2.4$ & $<1$ & $<1$ & $<1$ \\
White 11\% & $2.5-3.5$ & $1.7-1.9$ & $<1$ & $<1$ & $<1$ \\
\hline
\end{tabular}

${ }^{\mathrm{a}}$ Range of duplicate values. 


\section{Acknowledgements}

This research was supported by the Graduate School VLAG, Wageningen University, The Netherlands and Beijing WangZhiHe Sufu Manufacturer, China.

\section{References}

Andersson, A., Rönner, U., \& Granum, P. E. (1995). What problem does the food industry have with the spore-forming pathogens Bacillus cereus and Clostridium perfringens? International Journal of Food Microbiology, 28, 145-155.

Ashraf, H. R., White, M., \& Klubek, B. (1999). Microbiological survey of tofu sold in a rural Illinois county. Journal of Food Protection, 62(9), 1050-1053.

Brewer, M. S. (2000). Traditional preservatives-sodium chloride. In R. K. Robinson, C. A. Batt, \& P. D. Patel (Eds.), Encyclopedia of food microbiology (pp. 1723-1728). London: Academic Press.

Campbell-Platt, G. (1987). Fermented foods of the world. A dictionary and a guide. Guildford, Surrey, UK: Butterworth Scientific Ltd.

Chiou, R. Y., Ferng, S., \& Beuchat, L. R. (1999). Fermentation of lowsalt miso as affected by supplementation with ethanol. International Journal of Food Microbiology, 48, 11-20.

Granum, P. E. (1994). Bacillus cereus and its toxins. Journal of Applied Bacteriology Supplement, 76, S61-S66.

Han, B.-Z., Beumer, R. R., Rombouts, F. M., \& Nout, M. J. R. (2001a). Microbiological safety and quality of commercial sufu-a Chinese fermented soybean food. Food Control, 12, 541-547.

Han, B.-Z., Rombouts, F. M., \& Nout, M. J. R. (2001b). A Chinese fermented soybean food. International Journal of Food Microbiology, 65(1-2), 1-10.
Messens, W., Dewettinck, K., \& Huyghebaert, A. (1999). Transport of sodium chloride and water in Gouda cheese as affected by highpressure brining. International Dairy Journal, 9, 569-576.

Nout, M. J. R., \& Aidoo, K. E. (2002). Asian fungal fermented food. In H. D. Osiewacz (Ed.), The Mycota Vol. X. Industrial applications (pp. 23-47). Berlin: Springer-Verlag.

Pao, S.C. (1994). Halophilic organisms in sufu, Chinese cheese. The Ohio State University, PhD thesis, Order Number 9505268.

Rehberger, T. G., Wilson, L. A., \& Glatz, B. A. (1984). Microbiological quality of commercial tofu. Journal of Food Protection, 47, 177-181.

Seiler, D. A. L., \& Russell, N. J. (1991). Ethanol as a food preservative. In N. J. Russell, \& G. W. Gould (Eds.), Food preservatives (pp. 153-171). New York, USA: AVI.

Shi, X. R., \& Fung, D. Y. C. (2000). Control of foodborne pathogens during sufu fermentation and aging. Critical Reviews in Food Science and Nutrition, 40(5), 399-425.

Steinkraus, K. H. (1996). Chinese sufu. In K. H. Steinkraus (Ed.), Handbook of indigenous fermented foods (pp. 633-641). New York: Marcel Dekker, Inc.

Su, Y. C. (1986). Sufu. In N. R. Reddy, M. D. Pierson, \& D. K. Salunkhe (Eds.), Legume-based fermented foods (pp. 69-83). Florida, USA: CRC Press, Inc.

Tuitemwong, K., \& Fung, D. Y. C. (1991). Microbiological study of tofu. Journal of Food Protection, 54(3), 212-216.

Van Kooij, J. A., \& De Boer, E. (1985). A survey of the microbiological quality of commercial tofu in the Netherlands. International Journal of Food Microbiology, 2, 349-354.

Wang, H. L., \& Hesseltine, C. W. (1970). Sufu and Lao-Chao. Journal of Agricultural and Food Chemistry, 18(4), 572-575.

Wang, R.-Z., \& Du, X.-X. (1998). The production of Sufu in China (in Chinese). Beijing, China: China Light Industry Press (pp. 1-36).

Wijtzes, T., Bruggeman, M. R., Nout, M. J. R., \& Zwietering, M. H. (1997). A computerised system for the identification of lactic acid bacteria. International Journal of Food Microbiology, 38, 65-70. 